\title{
Effects of dietary deficiencies of protein and retinol on the plasma level of retinol-binding protein in the rat
}

\author{
By H. MUHILAL* aNd J. GLOVER \\ Biochemistry Department, University of Liverpool, PO Box 147, Liverpool L69 $3 B X$
}

(Received 30 Fanuary 1974-Accepted 26 February 1974)

\begin{abstract}
1. The plasma concentration of retinol-binding holoprotein (holo-RBP) in rats given retinol-sufficient diets containing $50 \mathrm{~g}$ soya-bean protein $/ \mathrm{kg}$ was $90 \%$ of the concentration found in controls given $200 \mathrm{~g}$ soya-bean protein $/ \mathrm{kg}$, whereas in rats given $5 \circ \mathrm{g}$ rice protein $/ \mathrm{kg}$ it was only $68 \%$ of the control value. Plasma albumin concentrations in the low-protein groups were lower by $20-25 \%$.

2. The rats given retinol-deficient diets, whose plasma levels of holo-RBP were reduced almost to zero after $5-8$ weeks, were given $\mathrm{I} \cdot 5 \mathrm{mg}$ retinol $/ \mathrm{kg}$ body-weight. Changes in plasma holo-RBP were measured for $7 \mathrm{~d}$. The rapid rise in the latter to a peak above normal control levels within $\mathrm{I}^{-5} \mathbf{5} \mathbf{2} \mathrm{h}$ indicated that a pool of the apoprotein had accumulated in the liver during the period of deficiency and that retinol was necessary for its release.

3. The maximum value reached in the groups of rats given the rice-protein diet was smaller than the values for the groups given the soya-bean-protein diets, reflecting a reduced rate of synthesis of the carrier protein in the livers of those groups.

4. The administration of $100 \mathrm{~g}$ casein $/ \mathrm{kg}$ diet to the rats receiving only $5 \circ \mathrm{g}$ rice-protein $/ \mathrm{kg}$ immediately stimulated the synthesis of the carrier protein which was released into plasma, reaching a peak after $24 \mathrm{~h}$ before settling down after $3-4 \mathrm{~d}$ to the steady-state level expected for normal well-nourished controls.

5. The half-life for excess holo-RBP released into plasma of rats receiving a normal level of good-quality protein was $7 \mathrm{~h}$, where it was $14 \mathrm{~h}$ for the groups of low-protein diets.
\end{abstract}

Retinol-binding protein (RBP) is synthesized in the liver and is the specific carrier for distributing retinol stored there to the tissues. The protein has been isolated from rat plasma and shown by Muto \& Goodman (1972) to be an $\alpha$-globulin. Since the synthesis of plasma proteins in the liver depends to a considerable extent on the pool of amino acids derived from the diet, the plasma level of RBP will probably be affected not only by the size of the available pool but also by its composition. Thus the amino acid supply is likely to affect RBP in the same way that the vitamin A status of the animal does. When the retinol reserves of the liver are exhausted, the normal secretion of the holoprotein (with retinol attached) is reduced and apoprotein (containing no retinol) accumulates. In the plasma, on the other hand, the level of the protein declines to one-third of the original value and only the apo-form is present (Muto, Smith, Milch \& Goodman, 1972). Administration of the vitamin brings about an immediate release of holoprotein from the liver and the plasma RBP rises temporarily for a few hours before finally returning to the original steady-state situation about $27 \mathrm{~h}$ later (Smith, Muto, Milch \& Goodman, 1973).

Previous studies on children suffering from protein-energy malnutrition also indicated that the dietary protein intake was important in addition to the supply of the vitamin for restoring the serum retinol level (Arroyave, Wilson, Mendez, Behar \&

* Present address: Biochemistry Laboratory, Nutrition Research Institute, Sembodja, Bogor, Indonesia. 
Table 1 . Composition $(\mathrm{g} / \mathrm{kg})$ of the diets given to rats

\begin{tabular}{|c|c|c|c|c|}
\hline Ingredient & $\begin{array}{c}\mathrm{I} \\
\text { (Control, } \\
\text { soya bean) }\end{array}$ & $\begin{array}{c}2 \\
\text { (Low } \\
\text { soya bean) }\end{array}$ & $\begin{array}{c}3 \\
\text { (Low } \\
\text { rice) }\end{array}$ & $\begin{array}{c}4 \\
\text { (Rice + } \\
\text { soya bean) }\end{array}$ \\
\hline Sucrose & 483 & 768 & 155 & - \\
\hline Soya-bean meal (defatted) & 400 & 100 & - & 200 \\
\hline Rice (whole) & - & - & 715 & 700 \\
\hline L-Methionine & 5 & $\mathrm{I} \cdot 5$ & - & - \\
\hline Arachis oil & 30 & 50 & 50 & 20 \\
\hline Choline chloride & 2 & 0.5 & - & - \\
\hline Mineral mixture" & 60 & 60 & 60 & 60 \\
\hline Vitamin mix in glucose $†$ & 10 & Io & 10 & I0 \\
\hline Fat-soluble vitamins in oilf & Io & ro & 10 & 10 \\
\hline $\begin{array}{l}\text { Crude-protein content } \\
\quad(\text { nitrogen } \times 5.7)\end{array}$ & 200 & 50 & 50 & $15^{\circ}$ \\
\hline
\end{tabular}

Scrimshaw, $196 \mathrm{I}$ ). Similar studies on pigs led to the same conclusion (Friend, Heard, Platt, Stewart \& Turner, I96r).

Oomen $\left(\mathrm{r}^{8} 5^{8}\right)$ commented that xerophthalmia is present in every region of Indonesia except possibly in some districts where maize forms the staple food and provides some provitamin A. One important dietary factor which appears to be common to all the affected people of Indonesia is that their main food is rice. Although maize provides a little provitamin $A$, whereas rice does not, it is thought that the high incidence of vitamin A deficiency in Indonesia is possibly due to the inadequacy of rice as a source of dietary protein. Teng ( 1968 ) also observed that the incidence of xerophthalmia increased during the rice harvest season and suggested a study on the effect of rice diet on the regulation of vitamin A metabolism. Therefore, in addition to studying the effect of retinol deficiency on plasma RBP concentration in the rat, experiments have also been carried out to examine the effects of low-protein diets, particularly diets containing rice protein.

\section{EXPERIMENTAL}

\section{Diets}

Table I shows the composition of the diets, all of which were deficient in vitamin A. The control diet was that of Lewin, Thompson, Pitt \& Howell (I970) and contained approximately $200 \mathrm{~g}$ soya-bean protein $/ \mathrm{kg}$ (diet I). A modified form of this diet contained $50 \mathrm{~g}$ soya-bean protein $/ \mathrm{kg}$ (diet 2). Another low-protein diet $(50 \mathrm{~g} / \mathrm{kg}$ ) was based on rice (diet 3 ) and the fourth diet contained $150 \mathrm{~g}$ protein $/ \mathrm{kg}$, one-third from rice, two-thirds from soya-bean meal (diet 4$)$. The crude protein content of all the diets was checked from the nitrogen content $\left(\times 5^{\circ} 7\right)$ determined by a micro-Kjeldahl procedure (Pearson, 1973). 


\section{Rat experiments}

Young male albino rats, Carworth-Europe CFHB strain, weighing 50-60 g, were divided $4 \mathrm{~d}$ after weaning into four groups, A-D, each containing six rats and of uniform mean weight. In Expt I, groups $\mathrm{A}$ and $\mathrm{B}$ were given the control diet and groups $\mathrm{C}$ and $\mathrm{D}$ the low-protein soya-bean $\operatorname{diet}(\operatorname{diet} 2)$. Groups $\mathrm{A}$ and $\mathrm{C}$ only were provided with adequate retinol $(3 \mathrm{mg} / \mathrm{kg}$ diet) to support growth, and the others (groups B and D) were given no retinol, to make them retinol-deficient. Three rats (group E) were also examined to establish the level of RBP at the start of the experiment. In Expt 2, five groups (F-J) of five rats each were used. Group $F$ was given diet $\mathrm{I}$ and groups $\mathrm{G}$ and $\mathrm{H}$ were given diet 4 . Groups $\mathrm{I}$ and $\mathrm{J}$ were given the lowprotein rice diet (diet 3 ). Groups $\mathrm{G}$ and I were given $3 \mathrm{mg}$ retinol $/ \mathrm{kg}$ diet and groups $\mathrm{H}$ and $\mathrm{I}$ received no retinol. A further four weanling rats (group $\mathrm{K}$ ) were examined at the start of the experiment to provide information on the starting levels of RBP in plasma and on the liver reserves of retinol.

\section{Preparation of plasma samples}

Each animal was lightly anaesthetized with Fluothane (ICI Ltd, London NW I) from a respirator and a small cut was made in the cleaned tail to allow a drop of blood to flow directly into a $100 \mu \mathrm{l}$ capillary tube. The tubes were immediately sealed at one end by dipping them into molten paraffin wax. These labelled tubes were placed in groups in centrifuge tubes and spun at $3000 \mathrm{~g}$ for $10 \mathrm{~min}$ and stored at $4^{\circ}$ in the dark until analysed shortly afterwards.

\section{Estimation of holo-RBP in plasma}

A plasma sample $(5 \circ \mu \mathrm{l})$ was taken, using a fine syringe needle, from each capillary tube and added with mixing to $5 \mathrm{mg}$ sucrose in a $0.5 \mathrm{ml}$ capacity glass tube with a tapered base mounted on a rubber block or rack. Two $20 \mu \mathrm{l}$ samples of the mixture were then subjected to standard disc-gel electrophoresis in a circular tank (Shandon Scientific Co. Ltd, London NW Io), followed by fluorimetric assay of the separated protein by the procedure described by Glover, Moxley, Muhilal \& Weston (1974) using a standard curve prepared from normal rat plasma.

\section{Estimation of protein and albumin in plasma}

The remainder of the plasma was then used for the determination of total protein by the Biuret micro-procedure (Gornall, Bardawill \& David, 1949) and of albumin by adsorption of bromocresol green (Bartholomew $\&$ Delaney, 1966). Some samples were also examined for albumin content by first resolving the protein electrophoretically on cellulose acetate strips using barbitone buffer ( $\mathrm{pH} 8 \cdot 6, \mathrm{i} 0 \cdot 05)$. They were then stained with Ponceau $\mathrm{S}$ and scanned with monochromatic light $(575 \mathrm{~nm})$ using a Zeiss PMQ II spectrophotometer with densitometer attachments. The amount albumin in the sample was determined by comparing the area of the albumin peak on the recording with the total area for all proteins in the electrophoretogram. There was good agreement between the results obtained by the two procedures. 


\section{Estimation of retinol in liver}

At the end of the experiment some rats were killed by chloroform inhalation and the livers were removed for determination of retinol. The liver tissue was homogenized and extracted with chloroform-methanol $(2: \mathrm{r}, \mathrm{v} / \mathrm{v})$ and separated into two phases by the addition of water. The chloroform phase was separated and samples taken for colorimetric analysis by the trifluoroacetic acid procedure of Neeld \& Pearson ( g $_{6} 6_{3}$ ).

\section{RESULTS}

Holo-RBP, total protein and albumin concentrations in the plasma of the various groups of rats in the two experiments are shown in Table 2.

Some residual, but very small, amounts of holo-RBP remained in the plasma of test groups B and D of Expt I even after 8 weeks on the retinol-deficient diets, but little or none was found in the plasma of the corresponding groups $\mathrm{H}$ and J in Expt 2 after 5 weeks. In addition the growth rate of all these depleted animals in the 8th or $5^{\text {th }}$ weeks had nearly reached zero, indicating that their tissues were depleted of the vitamin. This was confirmed by examination for retinol of the livers of four additional rats of the same size as those used in groups B and D (two in each group) and maintained on the same dietary regimens. They contained less than $0.5 \mu \mathrm{g}$ retinol $/ \mathrm{g}$ tissue.

The control groups $\mathrm{A}, \mathrm{F}$ and $\mathrm{G}$ given diets adequate in protein and retinol had uniform holo-RBP and albumin plasma concentrations of $27^{-28} \mu \mathrm{g} / \mathrm{ml}$ and $35^{-3} 3^{6} \mathrm{~g} / 1$ respectively. Group $\mathrm{C}$, given the low-protein soya-bean diet, showed a lower weight gain and a reduced plasma albumin content $(28 \mathrm{~g} / 1)$ but the holo-RBP level was decreased slightly, but significantly, to $25 \mu \mathrm{g} / \mathrm{ml}$. Group I rats on the other hand received the same level of protein in their diet as group $\mathrm{C}$ but the source was rice. 'These rats (group I) had a similar plasma level of albumin but a poorer growth rate and a substantially reduced level of holo-RBP, I $9 \mu \mathrm{g} / \mathrm{ml}(P<0.0 \mathrm{r})$.

After the vitamin-depletion period four animals from groups A-D of Expt $I$ and from groups $\mathrm{H}$ and $\mathrm{J}$ of Expt 2 were given single oral doses of approximately $\mathrm{I} \cdot 5 \mathrm{mg}$ retinol $/ \mathrm{kg}$ body-weight and the changes in plasma holo-RBP content were measured for $7 \mathrm{~d}$. The mean results for each group are shown in Fig. I for Expt I and in Fig. 2 for Expt 2. The single doses of retinol caused a rapid rise in the levels of holo-RBP in the plasma of groups B and D in Expt I where maximum concentrations of 53 and $44 \mu \mathrm{g} \mathrm{RBP} / \mathrm{ml}$ plasma respectively were reached at $2 \mathrm{~h}$ after dosing, greater than the control levels of $3^{\mathrm{I}} \mu \mathrm{g} / \mathrm{ml}$ (group A) and $26 \mu \mathrm{g} / \mathrm{ml}$ (group C) before decreasing to these control levels over the next $2-3 \mathrm{~d}$. The additional doses of retinol given to the normal animals did not alter their plasma level of holo-RBP. In Expt 2 where group J rats were given the low-protein, retinol-deficient rice diet, the changes in holo-RBP were similar but the $2 \mathrm{~h}$ peak value was $30 \mu \mathrm{g} / \mathrm{ml}$ plasma, which was much lower than the corresponding value $(46 \mu \mathrm{g} / \mathrm{ml})$ for the soya-bean-protein group $(\mathrm{H})$; the increase of I $\mu \mathrm{g} / \mathrm{ml}$ above the control level ( $9 \mu \mathrm{g} / \mathrm{ml}$ ) found in group I was appreciably less than that ( $18 \mu \mathrm{g} / \mathrm{ml}$ ) for the soya-bean groups. Thus the steady-state value of holo$\mathrm{RBP}(\mathrm{I} 9 \mu \mathrm{g} / \mathrm{ml}$ ) which was maintained by the low-protein rice diet was lower than 
Vol. $3^{2}$

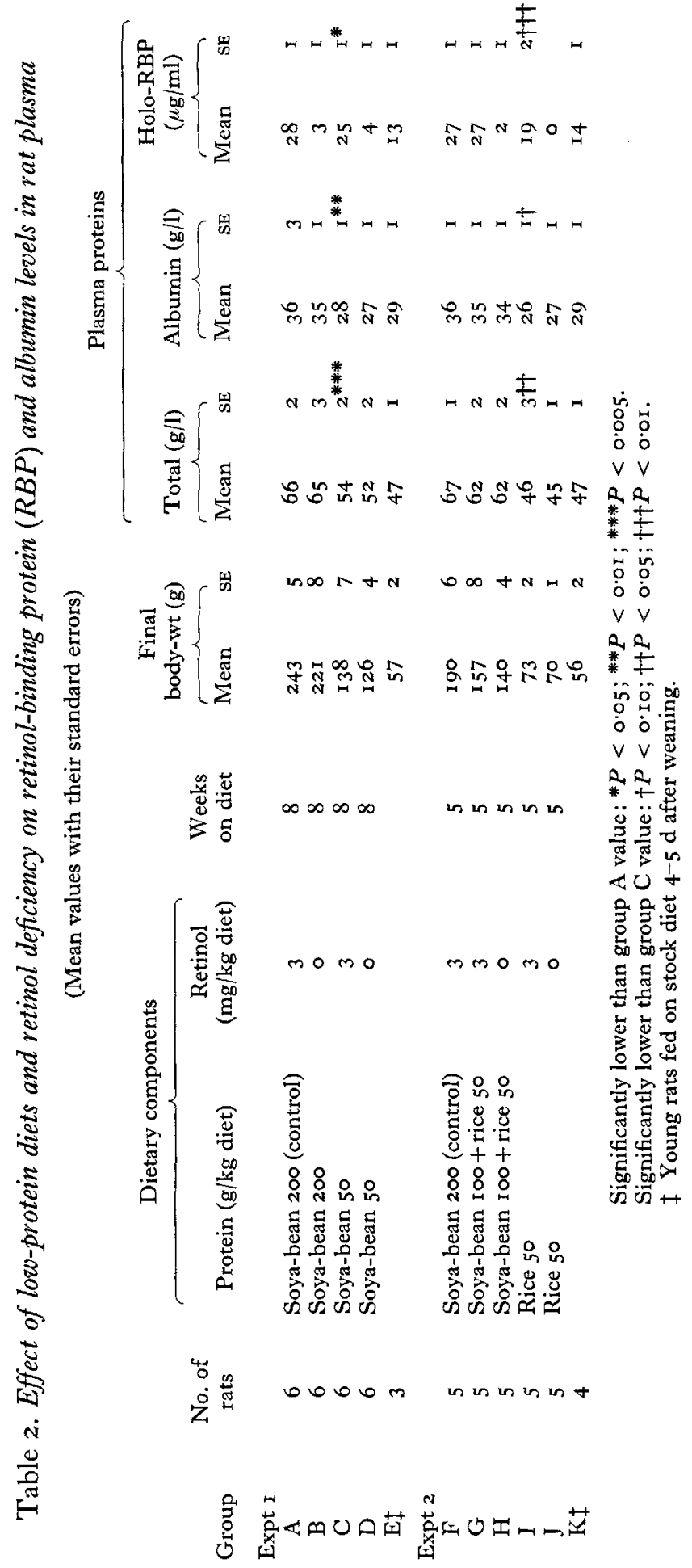




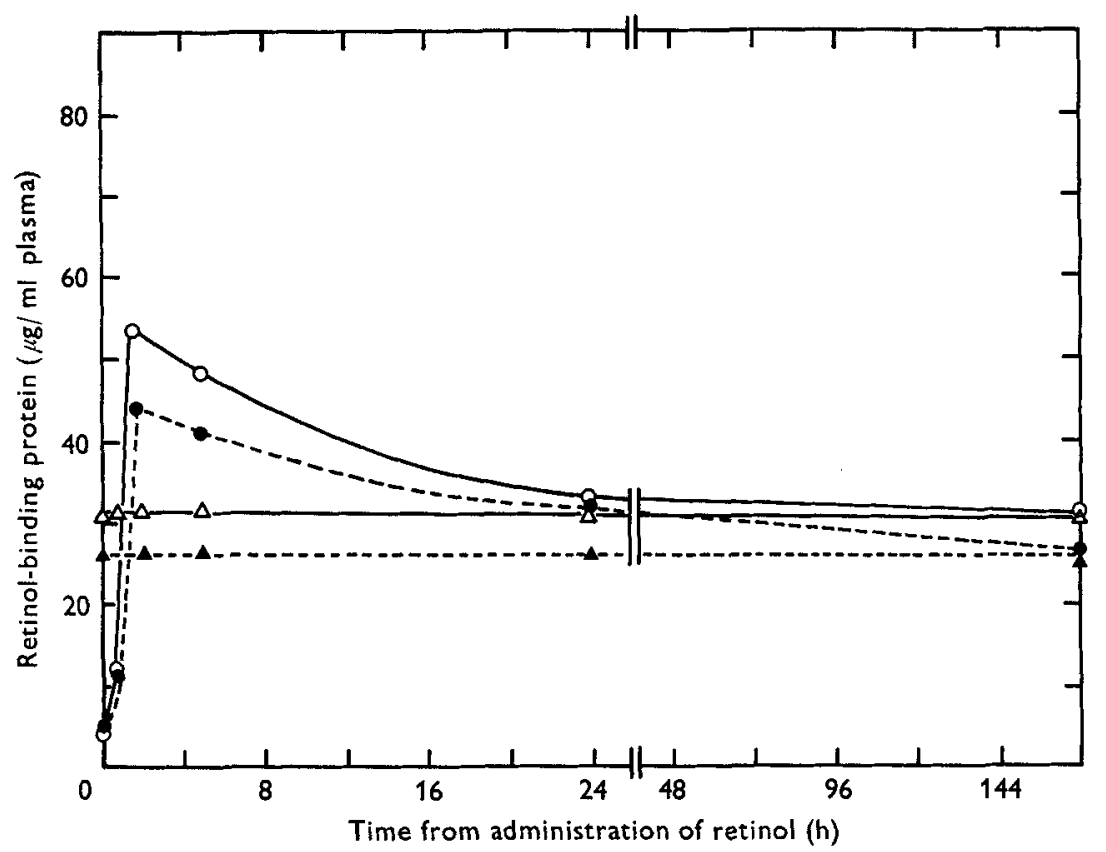

Fig. I. Expt I. Changes in retinol-binding protein concentration in plasma of retinol-deficient rats after receiving a single oral dose of retinol ( $1.5 \mathrm{mg} / \mathrm{kg}$ body-wt). Control groups A (200 $\mathrm{g}$ soya-bean protein $+3 \mathrm{mg}$ retinol $/ \mathrm{kg}$ diet $(\triangle-\triangle)$, and $\mathrm{C}(5 \circ \mathrm{g}$ soya-bean protein $+3 \mathrm{mg}$ retinol $/ \mathrm{kg}$ diet) $(\mathbf{\Delta}--\mathbf{\Delta})$; retinol-deficient groups $\mathrm{B}$ (200 g soya-bean protein $/ \mathrm{kg}$ diet) $(\mathrm{O}-\mathrm{O})$ and $\mathrm{D}$ (5०g soya-bean protein $/ \mathrm{kg}$ diet) (--). Mean values for four rats/group.

that for the control soya-bean-protein and the rice + soya-bean-protein diets $(27 \mu \mathrm{g} /$ $\mathrm{ml})$, and that for the group given an equivalent amount of soya-bean protein $(25 \mu \mathrm{g} / \mathrm{ml})$.

The effect of dietary protein was studied further by giving both groups of rats maintained on the low-protein rice diet ( $\mathrm{I}$ and $\mathrm{J}$ ), $7 \mathrm{~d}$ after group $\mathrm{J}$ had received the single dose of retinol, a daily supplement of casein ( $100 \mathrm{~g} / \mathrm{kg}$ diet) but no additional retinol. The changes in plasma holo-RBP and albumin concentrations were measured for Io $d$ and the results are presented in Fig. 3.

It can be seen that additional RBP was synthesized by both groups and released to yield a peak at $24 \mathrm{~h}$, higher than the one following retinol dosing (see Fig. 2), before returning to the steady-state level similar to that for animals on normal-protein diets. The albumin concentration (Fig. $3 a$ ), on the other hand, increased slowly and only reached the control level after $2 \mathrm{I} d$.

The uptake of retinol by the liver apparently removes the block in the final assembly of the holoprotein and enables an accumulated pool of surplus material to spill into the blood-stream. The rate of decline of this suddenly released protein was determined by plotting the excess over normal at successive time intervals on semi-log graph paper (Fig. 4). The half-life of holo-RBP in the rats on a good-quality-protein diet was found to be $7 \mathrm{~h}$ whereas the values for the animals on the low-protein diets were both much higher (about $\mathrm{I}_{4} \mathrm{~h}$ ).

In order to check that the plasma RBP levels found in the rats of groups B and D 


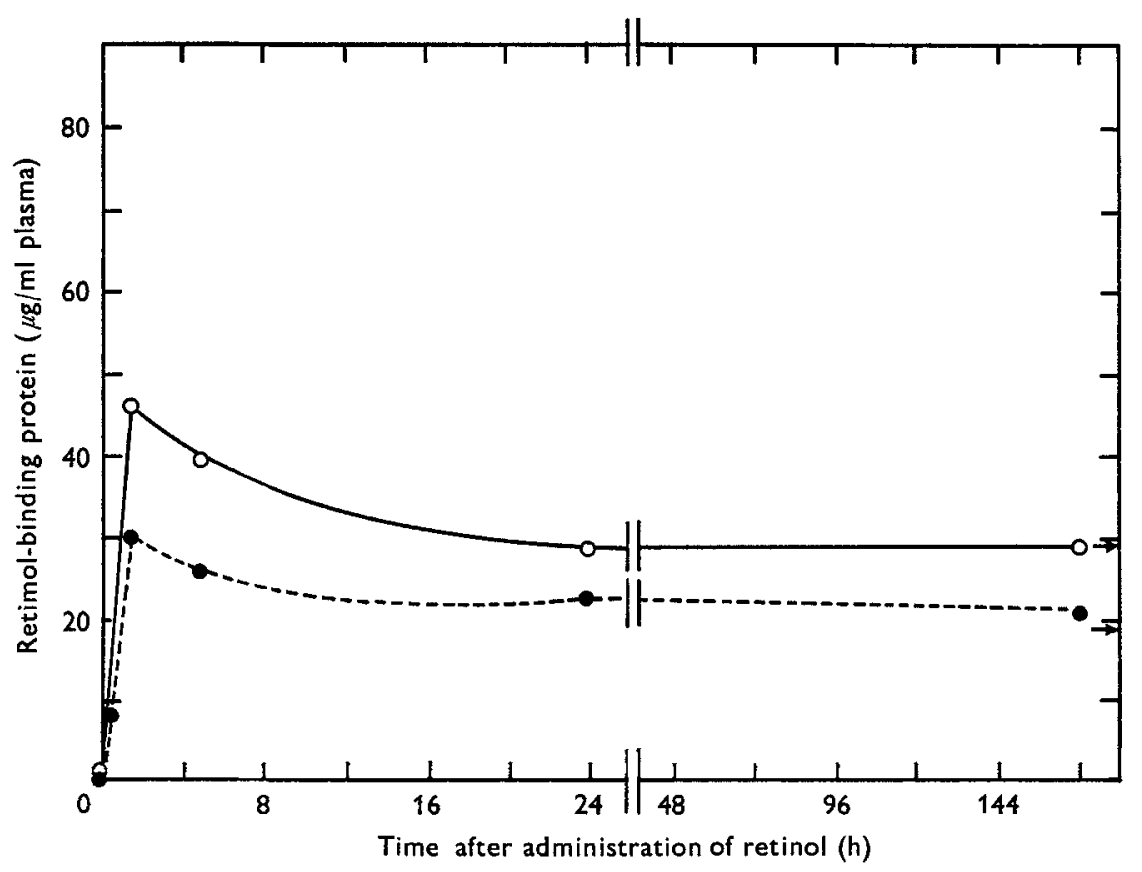

Fig. 2. Expt 2. Changes in retinol-binding protein concentration in plasma of retinol-deficient rats in groups $\mathrm{H}(\mathrm{O}-\mathrm{O})$ and $\mathrm{J}(--)$ given $\mathrm{roo}$ g soya-bean protein $+5 \circ \mathrm{g}$ rice protein $/ \mathrm{kg}$ diet and $50 \mathrm{~g}$ rice protein $/ \mathrm{kg}$ diet respectively, after they had been given a single oral dose of retinol $(1 \cdot 5 \mathrm{mg} / \mathrm{kg}$ body-wt). $\rightarrow$, Retinol-binding protein concentrations in plasma of control groups $G$ and $I$, retinol-supplemented ( $3 \mathrm{mg} / \mathrm{kg}$ diet), given the same diets as groups $H$ and $\mathrm{J}$ respectively. Mean values for four rats/group.

at the end of the experiment were supported by adequate liver reserves of the vitamin, the latter were estimated and found to lie in the range $35^{-40} \mu \mathrm{g} / \mathrm{g}$ tissue. This level was only slightly below that (50-60 $\mu \mathrm{g} / \mathrm{g}$ tissue) observed in the livers of four additional control rats maintained over the initial 8 weeks under the same conditions as groups $\mathrm{A}$ and $\mathrm{E}$ on retinol-supplemented diets and seen to be capable of supporting normal levels of RBP.

\section{DISCUSSION}

The results in Table 2 show that, for rats given adequate retinol, decreasing the dietary content of soya-bean protein from 200 to $50 \mathrm{~g} / \mathrm{kg}$ lowered the growth rate of the rats by $43 \%$ and the plasma albumin concentration by $20 \%$ (group C compared with A). The holo-RBP level of group $\mathrm{C}$, on the other hand, was maintained at only 10\% below the control value for group $\mathrm{A}(P<0.05)$ and should still have been adequate to transport sufficient retinol to the target tissues, provided there was sufficient reserve of the vitamin in the liver. This fall in holo-RBP level is similar to that previously reported by Deshmukh, Malathi \& Ganguly (1964), who found that plasma retinol concentration is low in rats maintained on a low-protein diet. The rats given $50 \mathrm{~g}$ rice-protein $/ \mathrm{kg}$ diet grew at only two-fifths of the rate of those fed on soya-bean protein; but after 5 weeks they were still lively and apparently healthy. Their plasma 


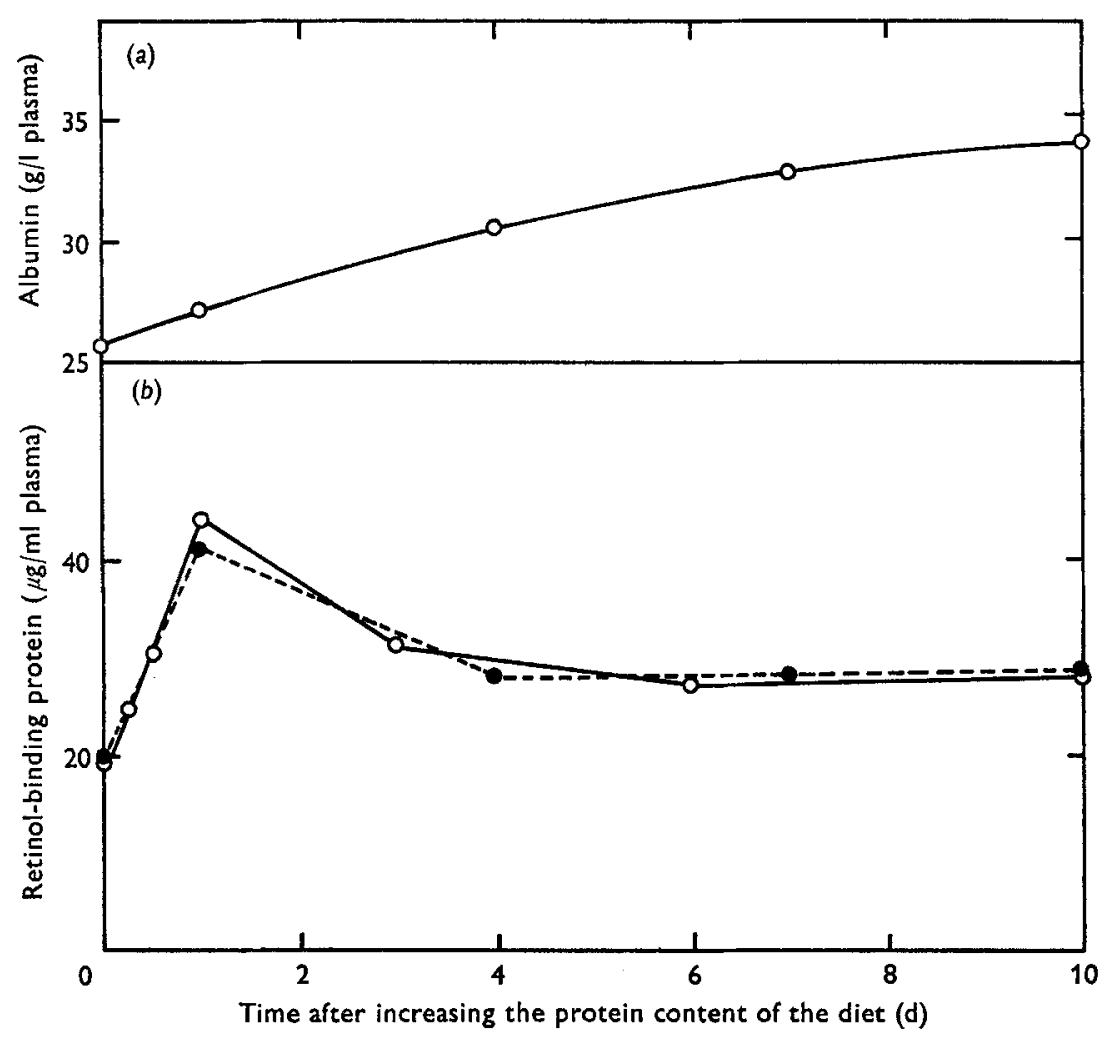

Fig. 3. Changes in (a) plasma albumin in rats of group $\mathrm{I}(\mathrm{O}-\mathrm{O})$ and $(b)$ retinol-binding protein concentrations in rats of groups $\mathrm{I}(\mathrm{O}-\mathrm{O})$ and $\mathrm{J}\left(\mathrm{O}_{-}-\mathrm{O}\right)$ receiving $5 \circ \mathrm{g}$ rice protein +3 and $0 \mathrm{mg}$ retinol $/ \mathrm{kg}$ diet respectively, when both groups were given a supplement of $100 \mathrm{~g}$ casein $/ \mathrm{kg}$ diet $7 \mathrm{~d}$ after group $\mathrm{J}$ had received a single oral dose of retinol $(\mathrm{r} \cdot 5 \mathrm{mg} / \mathrm{kg}$ body-wt). Mean values for four rats/group.

albumin levels were similar to those given the low-protein soya-bean diet but the holo-RBP concentration had dropped to two-thirds of the value for well-nourished controls $(P<0 \cdot 0 \mathrm{I})$. Thus the low-protein rice diet had a more deleterious effect on the synthesis of holo-RBP than on the synthesis of albumin.

The oral administration of retinol to all the retinol-deficient groups caused an increase within $45 \mathrm{~min}$ in the plasma holo-RBP concentrations, which reached peak values after $\mathrm{I}^{\prime} 5^{-2} \mathrm{~h}$. This supports the observations of Muto et al. (1972) that a pool of apo-RBP that accumulates in the liver of the retinol-deficient rat is quickly released into the blood-stream following the uptake of retinol.

The maximum plasma concentrations found in the rats given the low-protein diets were lower than the corresponding values for those receiving normal amounts of protein and presumably reflected the poorer capacity of the liver for synthesizing RBP under these conditions.

After the sudden release of RBP into the plasma, the level gradually returned after 2-3 $\mathrm{d}$ to that observed in the corresponding control groups given the same diets. For rats given the low-protein rice diet, it is clearly the limitation in protein and not in 


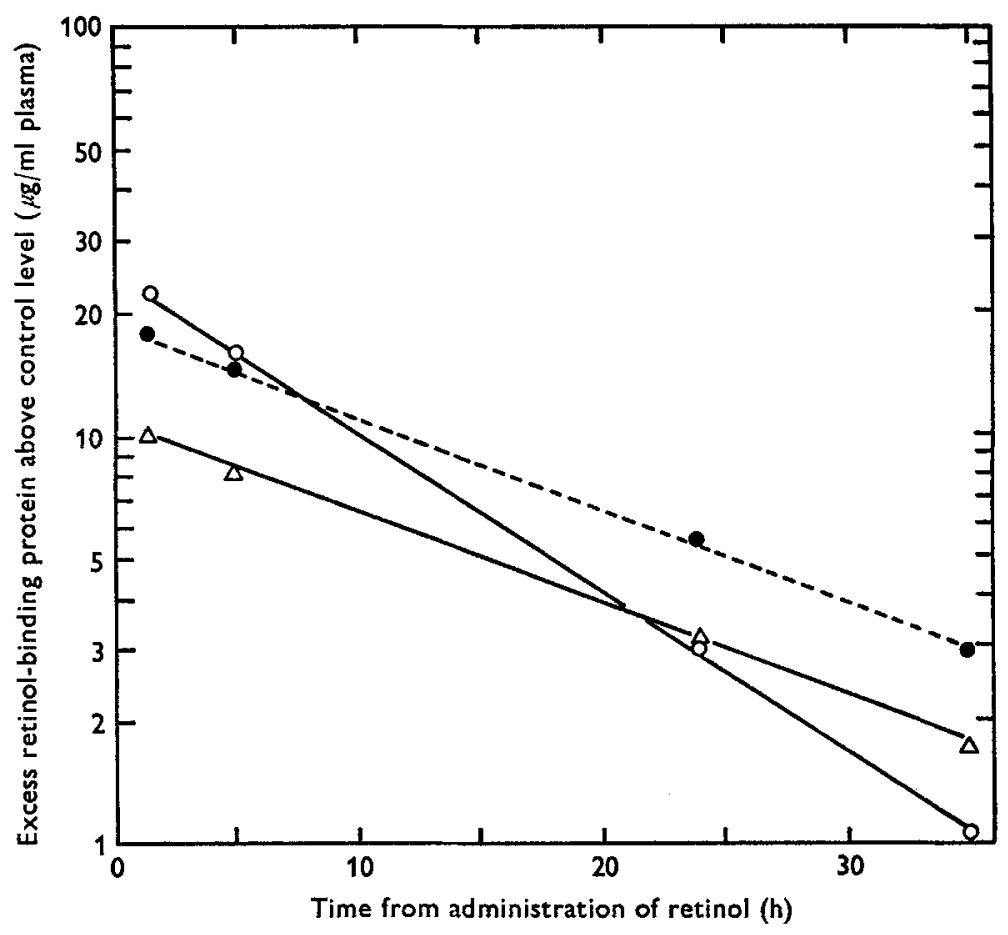

Fig. 4. Rate of decrease in the amount of excess retinol-binding protein released into the plasma following the administration of a single dose of retinol ( $1 \cdot 5 \mathrm{mg} / \mathrm{kg}$ body-wt) to the retinoldeficient rats. Group B ( $\mathrm{O}-\mathrm{O})$ given $200 \mathrm{~g}$ soya-bean protein/kg diet; group D (--O) given $50 \mathrm{~g}$ soya-bean protein $/ \mathrm{kg}$ diet and group $\mathrm{J}(\triangle-\Delta)$ given $5 \circ \mathrm{g}$ rice protein $/ \mathrm{kg}$ diet. Mean values for four rats/group.

retinol supply which controls the level of RBP reached. This was confirmed when both groups of rats were transferred to the better-quality-protein diet containing an additional roo $\mathrm{g}$ casein $/ \mathrm{kg}$ diet. The results in Fig. 3 show that within $24 \mathrm{~h}$ the concentration of RBP in plasma had risen well above the normal control level. The availability of a well-balanced amino acid supply quickly restored the capacity of the liver to synthesize RBP. Within a few days the excess RBP was metabolized and a new steady-state level of RBP was reached comparable to that found in normal wellnourished controls, reflecting the rapid turnover of this protein.

The half-life for the decline of the excess holo-RBP suddenly released into the plasma of the retinol-deficient rats given a normal diet (group B) was found to be about $7 \mathrm{~h}$, as shown in Fig. 4. This value is close to that obtained by Vahlquist (1972) for the decay of radioactively labelled RBP injected into the monkey and would imply that the turnover rates for RBP are comparable in these species.

The half-life for the metabolism of holo-RBP in the groups of animals given lowprotein diets at $14 \mathrm{~h}$, however, is twice that for normals, indicating the degree of adjustment that has taken place either in their protein metabolism to conserve valuable tissue proteins or in their requirement for retinol. This slower turnover of holo-RBP under these conditions explains in part the previously observed tendency 
for animals on such low-protein diets to preserve their liver stores of vitamin A (Rechcigl, Berger, Loosli \& Williams, 1962). It would be of interest to examine the effects on RBP of supplementing the rice protein with different important amino acids rather than with casein.

The rate of return of the albumin concentration towards the normal level of $3^{6} \mathrm{~g} / \mathrm{l}$ (groups $\mathrm{A}$ and $\mathrm{F}$ ) is shown in Fig. $3(a)$ for rats given the low-protein diet when a protein supplement was given. From the rate of decline of the difference between the control and test levels over this recovery period, the half-regeneration time of albumin can be calculated as approximately $4 \mathrm{~d}$, reflecting the much slower turnover time for plasma albumin compared with that for RBP. This value is only slightly longer than that $(3.3 \mathrm{~d})$ found for the half-life of albumin in the normal rat (Campbell, Cuthbertson, Mathews \& McFarlane, 1956) as might be expected. The rapid rise in the level of $\mathrm{RBP}$ in a protein-deficient subject following the ingestion of protein would seem therefore to be a useful indication of the restoration of a normal rate of protein synthesis by the liver, when adequate reserves of the vitamin are present in the animal.

In general, the above experiments indicate that it is necessary to maintain a good balance of amino acids in the diet to promote optimal RBP synthesis. A low level of protein of high biological value has less effect on the RBP level than the same level of a poorer-quality protein. At the same time it should be remembered that the maintenance of an adequate level of RBP places an increased demand on the available liver reserves of retinol, which as a consequence need frequent replenishment.

The authors wish to thank the World Health Organization $\left(\mathrm{N}_{3} / \mathrm{I} 8 \mathrm{I} / 5 \mathrm{I}\right)$ and the Medical Research Council (G970/77IB) for grants in support of the work and one of us (H.M.) for a Colombo Plan Research Fellowship.

\section{REFERENCES}

Arroyave, G., Wilson, D., Mendez, J., Behar, M. \& Scrimshaw, N. S. (196I). Am. F. clin. Nutr. 9, I80. Bartholomew, R. J. \& Delaney, A. D. (rg66). Proc. Aust. Ass. clin. Biochem. r, 2 I4.

Campbell, R. M., Cuthbertson, D. P., Mathews, C. H. \& McFarlane, A. S. (1956). Int. F. appl. Radiat. Isotopes I, 66.

Deshmukh, D. S., Malathi, P. \& Ganguly, J. (1964). Biochem. F. 90, 98.

Friend, C. J., Heard, C. R. C., Platt, B. S., Stewart, R. J. C. \& Turner, M. R. (I96ı). Br. F. Nutr. I5, 231 .

Glover, J., Moxley, L., Muhilal, H. \& Weston, S. ( I974). Clinica Chim. Acta 50, 37 I.

Gornall, A. G., Bardawill, C. J. \& David, M. M. (1949). . biol. Chem. 177, 75 I.

Howell, J. Mc., Thompson, J. N. \& Pitt, G. A. J. (1967). Br.F. Nutr. 21, 37.

Lewin, R., Thompson, J. N., Pitt, G. A. J. \& Howell, J. Mc. (1970). Int. Z. VitamForsch. 40, 270.

Muto, Y. \& Goodman, DeW. S. (1972). F. biol. Chem. 247, 2533.

Muto, Y., Smith, J. E., Milch, P. O.\& Goodman, DeW. S. (1972). F. biol. Chem. 247, 2542.

Neeld, J. B. Jr \& Pearson, W. N. (I963). J. Nutr. 79, 454.

Oomen, H. A. P. C. (1 958). Fedn Proc. Fedn Am. Socs exp. Biol. 17, Suppl. 2, i I I.

Pearson, D. (1973). Laboratory Techniques in Food Analysis. London: Butterworth \& Co. Ltd.

Rechcigl, M. Jr, Berger, S., Loosli, J. K. \& Williams, H. H. (1962). F. Nutr. 76, 435.

Smith, J. E., Muto, Y., Milch, P. O. \& Goodman, DeW. S. (1973). F. biol. Chem. 248, I 544.

Teng, K. H. (1968). Proc. Ist natn. Congr. Indonesian Ass. Ophthalmology p. 73.

Thompson, J. N., Howell, J. Mc., Pitt, G. A. J. \& McLoughlin, C. I. (1969). Br. F. Nutr. 23, 47 I.

Vahlquist, A. (1972). Scand. F. clin. Lab. Invest. 30, 349. 